\title{
Aluzja do rebelii Eugeniusza czy ukłon wobec aspiracji rzymskiej elity. Nowa interpretacja mowy Maeciusa Faltoniusa Nicomachusa (Hist. Aug. Tac. 6, 1-9)
}

The Reference to the Rebellion or Tribute to the Aspirations of the Roman Elite. New Interpretation of the Speech of Maecius Faltonius Nicomachus (Hist. Aug. Tac. 6, 1-9)

\section{STRESZCZENIE:}

Jak wiemy, Historia Augusta jest jednym z najbardziej enigmatycznych literackich źródeł późnej starożytności. Manuskrypty sugerują że Historia Augusta została napisana za panowania Dioklecjana i Konstantyna Wielkiego. Dziś jest prawie powszechnym konsensusem w historiografii, że Historia Augusta została napisana przez jednego autora, który żył wiele dekad później, niż sam sugeruje. Niektórzy współcześni badacze sądza, że autor Historia Augusta napisał swoje dzieło w ostatniej dekadzie IV wieku. Według ich sądów mowa wygłoszona w senacie przez Maeciusa Faltoniusa Nicomachusa w żywocie Tacyta jest aluzją do uzurpacji Eugeniusa. Mowa Nicomachusa nie odpowiada wstąpieniu na tron przez Tacyta. Oczywiście Scriptor nie jest tak dbały o prawdę historyczna, jak sam sugeruje, ale nie sądzę, aby ta mowa była aluzją do uzurpacji Eugeniusza. Prawdopodobnie potomkowie Aureliana, Tacyta i Probusa, których znamy z Historia Augusta, mogą być aluzją do rzymskich senatorów, którzy doszukiwali się przodków wśród dawnych rzymskich cesarzy.

Słowa kluczowe: słowa kluczowe: Historia Augusta, Tacyt, Aurelian, Probus, późne Cesarstwo Rzymskie, historiografia rzymska

Jak powszechnie wiadomo, Historia Augusta jest nie tylko najobszerniejszym źródłem poznania historii politycznej III w., ale też nastręcza więcej problemów niż inne dzieła antycznej historiografii ${ }^{1}$. Zawiera bo-

${ }^{1}$ Podstawowe informacje o Historia Augusta zob. R. Suski, Jowisz, Jahwe, Jezus. Religie w Historia Augusta, Warszawa 2014, s. 1-37, 359-386. 
wiem wiele dziwnych wiadomości, których nie sposób odnaleźć u innych autorów. Dziś wydaje się praktycznie pewne, że została napisana przez jedną osobę, choć w manuskryptach przypisuje się ją aż sześciu skądinąd nieznanym autorom. W samym dziele odnajdujemy liczne sugestie datujące powstanie poszczególnych biografii na panowanie Dioklecjana, jego współwładców i Konstantyna Wielkiego. Tymczasem terminus ante quem dla Historia Augusta to rok $369^{2}$. Przy tym najprawdopodobniej powstała ona wiele lat (kilka dziesięcioleci) po tej dacie, po śmierci Teodozjusza I ${ }^{3}$. Badacze próbując ustalić, kiedy została napisana, szukają w niej anachronizmów i aluzji do wydarzeń, które miały być współczesne jej autorowi. Istotne jest nie tylko, kto był autorem Historia Augusta (aby uniknąć powtórzeń dalej często będę go nazywać Scriptorem) czy kiedy powstała, ale też powód, dla którego zostało to ukryte. Wśród potencjalnych czynników często wymienia się względy polityczne, religijne i światopoglądo$\mathrm{we}^{4}$. Dobrze to pokazują interpretacje passusu pochodzącego z biografii Tacyta, w którym była cytowana mowa senatora Maeciusa Faltoniusa Ni-

${ }^{2}$ F. Paschoud, Historie Auguste, t. 4, 3, Vies des trente tyrans et de Claude, Paris 2011, s. 67-68; idem, On a recent book by Alan Cameron: The Last Pagans of Rome, "Antiquite Tardive" 2012, 20, s. 380. Jedynie nieliczni badacze błędnie opowiadają się za wcześniejszą datą. A. Lippold wierzy, że Historia Augusta powstała w czasach tetrarchów i Konstantyna Wielkiego, tak jak jest zapisane w manuskryptach dzieła. To jest jednak kompletnie nienaukowe, A. Lippold nie jest w w stanie polemizować z argumentami H. Dessaua (teksty A. Lippolda dotyczące Historia Augusta zostały zebrane w książce A. Lippold, Die Historia Augusta: eine Sammlung römischer Kaiserbiographien aus der Zeit Konstantins, Stuttgart 1998). Miażdząca recenzja poglądów A. Lippolda dotyczących Historia Augusta zawarta jest w recenzji napisanej przez T. D. Barnesa (T. D. Barnes, Rev. A. Lippold, Die Historia Augusta. Eine Sammlung römischer Kaiserbiographien aus der Zeit Konstantins, "Classical Review" 2000, 50, s. 306-307). Niedawno A. Cameron twierdzit, że terminus ante quem dla Historia Augusta to 361 rok (A. Cameron, The Last Pagans of Rome, Oxford 2011, s. 722). Niestety najwidoczniej nie zna on prac dotyczących Historia Augusta, które pokazują że ów autor musiał znać nie tylko brewiarium Aureliusa Victora, ale też Eutropiusa (zob. F. Paschoud, On a recent book..., s. 380). W każdym razie obaj badacze (A. Lippold i A. Cameron) pozostają poza głównym nurtem badań nad Historia Augusta.

${ }^{3}$ Zdecydowana większość badaczy uważa, ze Historia Augusta powstała w końcu IV lub na początku V wieku (zob. F. Paschoud, Histoire Auguste, t. 5, 1, Vies d'Aurélien, Tacite, Paris 1996, s. XIII). Jedynie nieliczni uczeni datują jej powstanie wcześniej. Tak według A. Camerona Historia Augusta powstała pomiędzy rokiem 361 a 385, gdyż jest od niej zależny Vita Hiliaronis Hieronima (A. Cameron, op.cit.., s. 761-772). W rzeczywistości o ile obaj autorzy przytaczają znaną z Cycerona opowieść o Aleksandrze Wielkim, który płakał na grobie Achillesa, to tekst Hieronima pod względem językowym jest bliższy oryginałowi niż Historia Augusta. Tak więc twierdzenie o znajmości przez Hieronima Historia Augusta jest kompletnie nieuzasadnione (patrz: F. Paschoud, On a recent book, s. 380). O tych passusach patrz: R. Suski, op.cit., s. 311-314.

${ }^{4}$ A. Chastagnol, Histoire Auguste. Les empereurs romains des II e et III e siècles, Paris 1994, s. CXXXIII-CLXXIV. 
comachusa. W tym tekście chcę pokazać inne sposoby rozumienia tego passusu oraz skrytykować dominującą metodę interpretowania tego jakże enigmatycznego źródła.

Sama mowa Maeciusa Faltoniusa Nicomachusa jest bardzo swoista. Rozwijane są w niej sukcesywnie trzy tematy ${ }^{5}$. W tej fikcyjnej wypowie$\mathrm{dzi}^{6}$ senator usprawiedliwia wybór starego cesarza przez senat. Według niego jest on doświadczony, sam wie, co znaczy być poddanym i będzie troszczył się o wszystkich, jakby był ojcem ${ }^{7}$. Następnie kwestionuje sprawowanie władzy przez młodych cesarzy, podając przykłady Nerona, Heliogabala czy Kommodusa. Ich wady wynikały w niewiększym stopniu z charakteru, jak młodości i braku u nich doświadczenia i życiowej mądrości ${ }^{8}$. Wreszcie uzasadnia wyższość przekazania władzy przez adopcję niż $\mathrm{w}$ ramach dziedziczenia. Senator domaga się od kandydata na cesarza, aby nie próbował przekazać tronu swoim synom, którzy są małymi dziećmi (parvulos)9. Ta mowa nie pasuje kompletnie do sytuacji, jaka miała miejsce po śmierci Aureliana. O ile rzeczywiście Tacyt był osobą

${ }^{5}$ F. Paschoud (ed.), Histoire Auguste, t. 5, 1..., s. 267.

${ }^{6} \mathrm{O}$ dokumentach w Historia Augusta patrz: L. Homo, Les documents de l'Histoire Auguste et leur valeur historique, "Revue Historique” 1926, 151, s. 161-198, 1927, 152, s. 1-31; B. Baldwin, Acclamations in the Historia Augusta, "Athenaeum” 1981, 59, s. 138-149; A. Chastagnol, op.cit., s. CXVIII-CXXVII.

${ }^{7}$ Hist. Aug. Tac. 6, 1-3 "Semper quidem, patres conscripti, recte atque prudenter rei publicae magnificus hic ordo consuluit, neque a quoquam orbis terrae populo solidior umquam exspectata sapientia est. attamen nulla umquam neque gravior neque prudentior in hoc sacrario dicta sententia est. seniorem principem fecimus et virum qui omnibus quasi pater consulat. nihil ab hoc inmaturum, nihil praeproperum, nihil asperum formidandum est. omnia seria, cuncta gravia, et quasi ipsa res publica iubeat, auguranda sunt. scit enim qualem sibi principem semper optaverit nec potest aliud nobis exhibere quam ipse desideravit et voluit".

${ }^{8}$ Hist. Aug. Tac. 6, 4-7 „Enimvero si recolere velitis vetusta illa prodigia, Nerones dico et Heliogabalos et Commodos, seu potius semper Incommodos, certe non hominum magis vita illa quam aetatum fuerunt. di avertant principes pueros et patres patriae dici impuberes et quibus ad subscribendum magistri litterarii manus teneant, quos ad consulatus dandos dulcia et circuli et quaecumque voluptas puerilis invitet. quae (malum) ratio est habere imperatorem, qui famam curare non noverit, qui quid sit res publica nesciat, nutritorem timeat, respiciat ad nutricem, virgarum magistralium ictibus terrorique subiaceat, faciat eos consules, duces, iudices quorum vitam, merita, aetates, familias, gesta non norit. sed quo diutius, patres conscripti, protrahor? magis gratulemur quod habemus principem senem, quam illa iteremus quae plus quam lacrimanda tolerantibus exstiterunt".

${ }^{9}$ Hist. Aug. Tac. 6, 8-9 "Gratias igitur dis inmortalibus ago atque habeo, et quidem pro universa re publica, teque, Tacite Auguste, convenio, petens, obsecrans ac libere pro communi patria et legibus deposcens, ne parvulos tuos, si te citius fata praevenerint, facias Romani heredes imperii, ne sic rem publicam patresque conscriptos populumque Romanum ut villulam tuam, ut colonos tuos, ut servos tuos relinquas. quare circumspice, imitare Nervas, Traianos, Hadrianos. ingens est gloria morientis principis rem publicam magis amare quam filios". 
zaawansowaną wiekowo (według Malalasa i Zonarasa został on zabity po sześciomiesięcznym panowaniu $\mathrm{w}$ wieku $75 \mathrm{lat}^{10}$ ), więc nawiązywanie do przymiotów starych ludzi było w tej mowie uzasadnione, to reszta argumentacji w niej użyta dziwi. Nie jest jasne, dlaczego autor Historia Augusta przeciwstawia zalety starości wadom młodości. Bardziej naturalne byłoby zestawienie cywilnych senatorów z wojskowymi. W końcu zarówno poprzednik, jak następca Tacyta należeli do tej drugiej grupy. W zawartej w Historia Augusta mowie wygłoszonej przez Tacyta (a raczej jemu przypisanej) przyszły cesarz przedstawiając swoje obiekcje dotyczące objęcia władzy zwraca uwagę na brak swoich kompetencji militarnych. Dziwi się on, że senatorowie chcą wybrać władcą starca, a nie mężczyznę w sile wieku' ${ }^{11}$. Ponadto nie wiadomo nam (poza Historia Augusta, ale o tych świadectwach będę pisać w dalszej części swojego tekstu), czy Aurelian dochował się dzieci ${ }^{12}$. Tak więc $\mathrm{w}$ roku 275 nikt nie mógł rozpatrywać obwołania cesarzem młodzieńca z racji urodzenia. Nie tylko sama mowa budzi spore wątpliwości, także nastręcza je imię mówcy. Nic nam nie wiadomo o istnieniu Maeciusa Faltoniusa Nicomachusa poza Historia Augusta. To nie jest jedyny przypadek, gdy w Historia Augusta pojawia się nomen Maecius (lub Maecianus) ${ }^{13}$. Nie są oni poświadczeni w innych źródłach, najprawdopodobniej więc zostali wymyśleni przez Scriptora ${ }^{14}$. Podobnie w Historia Augusta wspomniany jest jeszcze jeden enigmatycz-

${ }^{10}$ Mal. XII 31; Zon XII 28.

${ }^{11}$ Hist. Aug. Tac. 4, 5.

${ }^{12}$ Niewiele wiemy o rzeczywistych krewnych Aureliana. Według Eutropiusa okrucieństwo cesarza było tak wielkie, że kazał zabić swojego siostrzeńca (Eutrop. Brev. IX 14). Ten sam przekaz odnajdujemy w Epitome de caesaribus (Epit. 35, 9). Zapewne informacja pochodzi ze wspólnego dla nich źródła lub anonimowy dla nas autor Epitome de Caesaribus znał pracę Eutropiusa. Wspomina o tym także autor Historia Augusta, który informuje czytelnika o straceniu siostrzeńca władcy, choć wielu miało mówić, że był nim syn albo córka (Hist. Aug. Aurel. 39, 9). Wcześniej Scriptor wspominał o zamordowaniu siostrzenicy imperatora, co wywołano nienawiść krewnych (Hist. Aug. Aurel. 36, 3).

${ }^{13}$ Są to: Baebius Maecianus, krewny Clodiusa Albinusa (Hist. Aug. Clod. Alb. 6, 1), Maecius Marullus, ojciec Gordiana I (Hist. Aug. Gord. 2, 2), Maecia Faustina, córka Gordiana I (Hist. Aug. Gord. 4, 2), Maecius Gordianus, prefekt pretorianów Gordiana III, a zarazem jego krewny (Hist. Aug. Gord. 30, 2), Maecius Brundisinum, praefectus annonae Orientis za Waleriana (Hist. Aug. Val. 13, 1), Cereius Maecianus, comes, który otrzymał list od Claudiusa Maecianusa (Hist. Aug. Tac. 13, 3) i Maecianus, do którego napisał list uzurpator Proculus, chwaląc się swoimi seksualnymi wyczynami z sarmackimi brankami (Hist. Aug. Quad. tyr. 12, 7).

${ }_{14}^{14}$ R. Syme, Ammianus and the Historia Augusta, Oxford 1968, s. 163. Dotyczy to też prefekta Maeciusa Gordianusa (R. Syme, Emperors and Biography, Oxford 1971, s. 4; A. Chastagnol, op.cit., s. 736; S. Ruciński, Praefecti praetorio. Dowódcy gwardii pretoriańskiej od 2 roku przed Chr. do 282 roku po Chr., Bydgoszcz 2013, s. 605). 
ny Nicomachus ${ }^{15}$, którego nie można traktować jako postać historyczną. Powstaje więc pytanie, z jakiego powodu autor Historia Augusta wymyślił mowę i czemu ona służy.

Według W. Hartkego skoro mowa Maeciusa Faltoniusa Nicomachusa nie pasuje do sytuacji z czasów panowania Tacyta, to zapewne jest ona aluzją do wydarzeń z czasów powstania Historia Augusta (co datuje na rok 393-394), gdy Teodozjusz I wysunął swojego młodocianego syna Honoriusza do rządów nad zachodem cesarstwa ${ }^{16}$. Hipotezę rozwinął Honoré. Według niego mowa miała być wyrazem poparcia dla Eugeniusza przeciw wyniesieniu do władzy Honoriusza. Imię mówcy miało nawiązywać do postaci Viriusa Nicomachusa Flavianusa St. (cos. 394), jednego z najważniejszych sojuszników Eugeniusza ${ }^{17}$. Gdyby mieli oni rację, to należałoby w Historia Augusta widzieć propogański i prosenatorski pamflet, co miałoby olbrzymie znaczenie w interpretacji tego dzieła i opisywanych przez nie faktów. Hipoteza znalazła wielu zwolenników ${ }^{18}$. Wręcz wymienia się go za jeden z trzech passusów, które pozwalają datować Historia Augusta ${ }^{19}$. Choć zdecydowana większość badaczy umiejscawia powstanie dzieła na czas już po śmierci Teodozjusza $\mathrm{I}^{20}$, to niewiele osób polemizuje z ową hipotezą.

Do tej pory hipotezę Hartke-Honoré najmocniej atakował A. Cameron. Zwrócił on uwagę, że przed Teodozjuszem I następcami władców byli ich młodociani synowie. Spadkobiercami Walentyniana I byli jego synowie Gracjan i Walentynian II, a autorzy żyjący w drugiej połowie IV

${ }^{15} \mathrm{~W}$ żywocie Aureliana wspominany jest bardzo enigmatyczny Nicomachus, który przetłumaczył list Zenobii do Aureliana z syryjskiego na grekę (Hist. Aug. Aurel. 27).

${ }^{16}$ W. Hartke, Römische Kinderkaiser. Eine Strukturanalyse römischen Denkens und Daseins, Berlin 1951, s. 413. Jak wiadomo, Arkadiusz urodził się ok. 377 r. (Soc. Hist. Eccl. VI 23, 7; Cedr. 334c),. Został on obwołany augustem w 383 r., gdy miał 6 lat. W chwili śmierci swojego ojca był osiemnastolatkiem. Honoriusz urodził się w 388 r. (Cons. Const. 384; Soc. Hist. Eccl. V 12, 2). W 393 r., gdy został ogłoszony augustem, miał 5 lat, a w chwili śmierci swojego ojca 7 lat.

${ }^{17}$ T. Honoré, Scriptor Historiae Augustae, JRS 1987, 77, s. 173-176. Badacze, którzy doszukiwali się w tej mowie aluzji do synów Teodozjusza I i rebelii Eugeniusza, w postaci Maeciusa Faltoniusa Nicomachusa widzieli nawiązanie do kilku postaci z końca IV wieku. Tak cognomen Nicomachus byłby ukłonem w stronę Viriusa Nicomachusa Flavianusa St. lub jego syna Viriusa Nicomachusa Flavianusa Mł. Cognomen Faltonius mógł być nawiązaniem do Faltoniusa Probusa Alypiusa, chrześcijanina i PVR w latach 392-394. Nomen Maecius byłby zaś aluzją do Furiusa Maeciusa Gracchusa, PVR w latach 376-377. Zob. F. Paschoud (ed.), Histoire Auguste, t. 5, 1, s. 265.

${ }^{18}$ Zob. A. Chastagnol, op.cit., s. CLXI-CLXII.

${ }^{19}$ Zob. F. Paschoud, (ed.), Histoire Auguste, t. 5, 1, s. XV.

${ }^{20}$ Ibidem, s. XIII-XVIII. 
wieku zwracają uwagę na ich młody wiek ${ }^{21}$. Do tego nie widać, aby chrześcijanie lepiej byli ustosunkowani do rządów młodocianych imperatorów niż poganie ${ }^{22}$. O ile rzeczywiście krytyka sprawowania władzy przez dzieci-imperatorów nie musi być związana z objęciem tronu przez Honoriusza i może dotyczyć cesarzy zarówno wcześniejszych, jak i późniejszych (Walentynian III został augustem w wieku sześciu lat), to rozumowanie Camerona jest co najmniej dziwne. Kompletnie zignorował on argument dotyczący imienia fikcyjnego mówcy w biografii Tacyta, co w przypadku tej hipotezy jest ważne. Nie tłumaczy też, dlaczego właśnie w tym miejscu autor Historia Augusta tak dobitnie przedstawia swój pogląd na rządy młodocianych cesarzy. Wreszcie młodociani cesarze w końcu IV wieku byli chrześcijanami, a nie poganami, więc dla tych drugich mógł być to argument $\mathrm{w}$ sporze $\mathrm{z}$ tymi pierwszymi ${ }^{23}$.

Rozsądniej hipotezę Hartke-Honoré krytykuje F. Paschoud. Po pierwsze - zwraca on uwagę, ze nie jest to jedyne miejsce, w którym autor $\mathrm{Hi}$ storia Augusta twierdzi, że nie urodzenie, a bycie najlepszym winno decydować o następstwie tronu ${ }^{24}$. Podkreśla bowiem, że Quintillus został obwołany cesarzem dla przymiotów, a nie ze względu na dziedziczenia po bracie $^{25}$. Tacyt obiecał w senacie, że nie powierzy władzy swoim synom, ale komuś najlepszemu. Mimo to Florianus ogłosił się imperatorem, jakby władza nad państwem była dziedziczna ${ }^{26}$. Karus byłby lepszym cesarzem, gdyby nie zostawił Karinusa jako swojego następcy ${ }^{27}$. W żywocie Septimiusa Severusa, kierując słowa do Dioklecjana, zwracał on uwagę, że pra-

${ }^{21}$ A. Cameron, op.cit., s. 751-752. Gracjan został władcą w 367 r. jako ośmiolatek, a Walentynian II w 375 r. jako czterolatek. W chwili śmierci swojego ojca Gracjan miał 16 lat. Na wiek cesarzy zwracał uwagę Zosimos, który twierdził, że ze względu na młody wiek nie sprawowali oni faktycznej władzy (Zos. Hist. IV 19, 2). Na wiek Gracjana jako władcy zwracali uwagę też Symmachus (Symm. Or. III 23) i Themistios, nazywający imperatora pięknym dzieckiem (hoi pai kale; Them. Or. XIII 165d; 171a). Co ciekawe, Symmachus był pogańskim tradycjonalista, a dzieło Zosimosa ma jawnie pogański charakter. Patrz: A. Chastagnol, op.cit., s. CLXI-CLXII

${ }^{22}$ A. Cameron, op.cit., s. 752. Powołuje się na świadectwa Bazylego Wielkiego (Basil. Hex. VIII 4) czy Ambrożego (Amb. Hex. V 68).

${ }^{23} \mathrm{~W}$ tym miejscu trudno powiedzieć, co powodowało A. Cameronem w takim sposobie prowadzenia dyskusji ze swoimi adwersarzami. Niestety jest to dosyć typowe dla niego. Zwraca na to uwagę F. Paschoud, który w recenzji The Last Pagans przyrównuje sposób referowania poglądów innych badaczy przez Camerona do radzieckiej „Prawdy”. Zob. F. Paschoud, On a recent book..., s. 360-361.

${ }^{24}$ F. Paschoud (ed.), Histoire Auguste, t. 5, 1, s. 271.

${ }^{25}$ Hist. Aug. Claud. 12, 3.

${ }^{26}$ Hist. Aug. Tac. 14, 1; Hist. Aug. Prob. 10, 8; 11, 3.

${ }^{27}$ Hist. Aug. Car. 3, 8. 
wie żaden z wielkich mężów nie pozostawił wybitnego syna ${ }^{28}$. Wymieniał przykłady Numy Pompiliusa, Camillusa, Scypiona, Katonów, Homera, Demostenesa, Wergiliusza, Terencjusza, Plauta, Cezara, Cycerona czy Augusta $^{29}$. Według niego Marek Aureliusz byłby szczęśliwszy, gdyby swoim następcą nie uczynił Kommodusa. Podobnie było z Septimiusem Severusem i Karakallą ${ }^{30}$. Ta teza nie jest wynalazkiem Scriptora, ale powoływali się na nią także inni rzymscy autorzy. W Historiae Tacyta Galba adoptując L. Calpurniusa Piso Frugi Licinianusa zadeklarował, że namiastką wolności będzie wybór władcy wśród najlepszych, gdyż urodzić się w rodzinie cesarskiej jest dziełem przypadku, a przez adopcję ma się swobodny wybór $^{31}$. Galba wybrał Calpurniusa Pisona, lekceważąc względy pokrewieństwa, gdyż był daleki od namiętności młodości i posiadał wiele zalet ${ }^{32}$. Podobnie Pliniusz Mł. w Panegiryku wygłoszonym pod adresem Trajana zwracał uwagę, że pokrewieństwo nie łączyło adoptowanego z adoptującym, nie byli oni przyjaciółmi, po prostu obaj uchodzili za najlepszych i dlatego jeden był godny, żeby go wybrać, i drugi - że tego dokonał. Według Pliniusza Mł. szukając następcy tronu powinno się kierować zasada, że kto zamierza rozkazywać wszystkim, spośród wszystkich winien być wybrany. Co więcej, wyrazem zarozumialstwa graniczącego wręcz z despotyzmem byłaby sytuacja, gdyby się nie zaadoptowało tego, o którym powszechnie wiadomo, iż będzie sprawował władzę najwyższąą3. Podobną myśl odnajdujemy także u Aureliusa Victora ${ }^{34}$. Tak więc nawoływanie do wykluczania młodych synów cesarzy nie musi być związane z aluzją do konkretnych wydarzeń politycznych, a jest elementem rzymskiego dyskursu politycznego.

Po drugie - Maecius Faltonius Nicomachus zaapelował do Tacyta, aby obiecał, że władzę po sobie nie przekaże swoim młodym synom, a najlepszym. F. Paschoud zauważał, że Eugeniusz nie posiadał dzieci (a przynajmniej nic o tym nie wiemy), więc nie ma podobieństwa pomiędzy nim a Tacytem w Historia Augusta ${ }^{35}$. Co więcej, przy takiej interpretacji tej

${ }^{28}$ Hist. Aug. Sev. 20, 4-5. Należy zwrócić uwagę, że wypowiedź jest skierowana do Dioklecjana, który pozostawił po sobie jedynie córkę. Autor Historia Augusta próbował sprawiać wrażenie, że pisze za czasów tego cesarza. Tak więc cały passus o braku godnych synów przez ludzi wielkich może nie pokazywać rzeczywistych poglądów Scriptora, ale ma na celu uwiarygodnić fikcyjną datację jego dzieła.

${ }^{29}$ Hist. Aug. Sev. 21, 1-3.

${ }^{30}$ Hist. Aug. Sev. 21, 5.

${ }^{31}$ Tac. Hist. I 15-16.

${ }^{32}$ Tac. Hist. I 15.

${ }^{33}$ Plin. Paneg. 7, 5-6.

${ }^{34}$ Aur. Vict. De Caes. 13, 13.

${ }^{35}$ F. Paschoud (ed.), Histoire Auguste, t. 5, 1, s. 272. 
mowy nie ma potrzeby wyjaśniania nazwiska senatora wygłaszającego ja, gdyż jest to bez znaczenia dla jej sensu.

O ile dyskurs F. Paschouda jest bardzo ciekawy, to nie do końca stanowi odpowiedź na pytanie, dlaczego Scriptor omawiając wybór Tacyta na cesarza wspomniał o młodocianych władcach ${ }^{36}$. Nic nie wskazuje na to, aby Tacyt pozostawił po sobie dzieci, a przynajmniej nie sugerują tego źródła poza Historia Augusta (więcej o tym dalej). Wypowiedzieć Maeciusa Faltoniusa Nicomachusa usprawiedliwiałaby, dlaczego wymyśleni synowie Tacyta nie wstąpili na tron po śmierci swojego ojca. Ale pozostaje pytanie, dlaczego Scriptor czyni to w tym miejscu. Przecież wirtualni spadkobiercy Tacyta nie wstąpili na tron, gdyż ich potencjalny ojciec został zamordowany przez żołnierzy. Nie było więc potrzeby wspominać ich podczas dyskusji o następstwie tronu po Aurelianie. Nieistniejący w rzeczywistości potomkowie Tacyta stracili szanse na tron przez obwołanie cesarzem Probusa. Ten ostatni jest przedstawiany w Historia Augusta jako ideał cesarza ${ }^{37}$. Tak więc wspomnienie pominięcia ich pretensji do tronu byłoby bardziej racjonalne podczas przedstawienia dyskusji o zatwierdzeniu panowania Probusa niż Tacyta. A w tamtym passusie wspominany jest jedynie Florianus ${ }^{38}$. Tak więc sądzę, że w tej narracji brakuje czegoś, aby wytłumaczyć jej sens.

Po pierwsze, zauważmy, że mowa, którą miał wygłosić Maecius Faltonius Nicomachus, jest częścią większej całości, opisu ogłoszenia Tacyta cesarzem. Ta długa narracja jest najobszerniejszą częścią całej biografii Tacyta. Obejmuje ona mniej więcej $1 / 3$ całości. Dosyć łatwo to wytłumaczyć. Panowanie Tacyta było krótkie, jego panowanie nie obfitowało $\mathrm{w}$ wiele wydarzeń politycznych (poza walkami z Gotami i ukaraniem morderców Aureliana). Scriptor musiał więc jakoś wypełnić swój przekaz. Do tego skupienie się na opisie ogłoszenia cesarzem Tacyta podyktowane było ideologicznie. Tacyt został wybrany przez senat, co było bliskie autorowi Historia Augusta, który był zwolennikiem silnej pozycji senatu w systemie władzy w państwie rzymskim.

Po drugie, bardzo trudno wskazać też, jakie mogły być źródła Scriptora dla tych passusów. Najczęściej sugeruje się, że w tej części pracy głów-

${ }^{36}$ Paradoksalnie sam F. Paschoud wykorzystuje mowę Maeciusa Faltoniusa Nicomachusa do datowania Historia Augusta na po 395 r., czyli w dużym stopniu podąża śladem Hartkego i Honoré (z tą różnica, że on sądzi, że passus jest aluzją do synów Teodozjusza I po jego śmierci, a nie przed), zob. F. Paschoud (ed.), Histoire Auguste, t. 5, 1..., s. XV.

${ }^{37}$ M. Baranowski, Przedcesarskie gesta Probusa, czyli kariera idealnego pryncepsa w Historia Augusta, „U Schyłku Starożytności” 2014, 13, s. 85-99.

${ }^{38}$ Hist. Aug. Prob. 11, 1-5. 
nym źródłem dla Historia Augusta była tajemnicza Kaisergeschichte ${ }^{39}$. Dzieło to nie zachowało się do naszych czasów i wcale nie jest oczywiste, czy rzeczywiście istniało ${ }^{40}$. W biografii Tacyta odnajdujemy ślady znajomości tradycji obecnej $\mathrm{u}$ Aureliusa Victora ${ }^{41}$, ale dotyczy to jedynie najbardziej ogólnych faktów. Co prawda w tym passusie autor Historia Augusta powołuje się na źródło Liber Elephantius, ale to dzieło jest jego wymysłem². Przy tym nie tylko mowa Maeciusa Faltoniusa Nicomachusa jest wątpliwą częścią tej narracji. Nie było opisywanego przez Historia Augusta sześciomiesięcznego interregnum pomiędzy rządami Aureliana a Tacyta ${ }^{43}$. Data proklamacji cesarskiej Tacyta, podana przez Scriptora, jest z całą pewnością błędna ${ }^{44}$. Nie jest jasne, co autor Historia Augusta miał na myśli, kiedy

${ }^{39}$ F. Paschoud (ed.), Histoire Auguste, t. 5, 1, s. 230-231.

40 Literatura dotycząca Kaisergeschichte jest ogromna. Podstawową czytelnik odnajdzie: T. D. Barnes, The Lost Kaisergeschichte and the Latin Historical Tradition, „Bonner Historia Augusta Colloquium" 1968/69, Bonn 1970, s. 13-43; B. Bleckmann, Überlegungen zur Enmannschen Kaisergeschichte und zur Formung historischer Traditionen in tetrarchischer und konstantinischer Zeit, [w:] Historiae Augustae Colloquium Bonnense. Bari 1997, s. 11-37; R. W. Burgess, Principes cum Tyrannis. Two Studies on the Kaisergeschichte and its Tradition, "The Classical Quarterly" 1993, 43, s. 491-500; idem, On the Date of the Kaisergeschichte, "Classical Philology" 1995, 90, s. 111-128; idem, A Common Source for Jerome, Eutropius, Festus, Ammianus, and the Epitome de Caesaribus between 358 and 378, along with Further Thoughts on the Date and Nature of the Kaisergeschichte, "Classical Philology" 2005, 100, s. 166-192; F. Chausson, «Severus, XVII, 5 - XIX, 4: une identification?», [w:] Historiae Augustae Colloquium Bonnense, Bari 1997, s. 97-113.

${ }^{41}$ F. Paschoud (ed.), Histoire Auguste, t. 5, 1, s. 230.

${ }^{42}$ Ibidem, s. 276-277.

${ }^{43}$ Aurelius Victor wspomina o nastąpieniu po śmierci Aureliana okresu niepokoju, jakby interregnum (De Caes. 35, 12). O tym pisze też zależne od niego Epitome de Caesaribus (Epit. 35, 10). Najprawdopodobniej Aurelius Victor miał na myśli krótkie rządy Tacyta jako interregnum pomiędzy panowaniem Aureliana a Probusa (Th. M. Banchich, The History of Zonaras from Alexander Severus to the Death of Theodosius the Great, London-New York 2009, s. 125). Prawdopodobnie więc Scriptor nie zrozumiał przekazu zawartego u Aureliusa Victora.

${ }^{44}$ Aurelian był wspominany w dokumentach jako cesarz 19 X 275 r. (P.Oxy, XII, 1455, 20-26). W materiale papirologicznym Tacyt poświadczony jest jako władca od $9 \mathrm{~V} 276 \mathrm{r}$. (P. Cairo Isid, 108, 17-19), ale wszystko wskazuje na to, że objął władzę przed 10 XII 275 r. (znamy inskrypcje, na których podaje się drugą tribunicia potestas Tacyta). Przy tym autor Historia Augusta twierdził, że ogłoszenie Tacyta cesarzem nastąpiło 6 miesięcy po śmierci Aureliana. To nie pierwszy przypadek, w którym podaje on ewidentnie błędną datę obrad senatu. Senat miał ogłosić cesarzami: Aleksandra Sewera 6 III 222 r. (Hist. Aug. Alex. Sev. 6, 2.), Gordiana I i Gordiana II 26 VI 238 r. (Hist. Aug, Max. 16, 1), Pupienusa i Balbinusa 7 VI 238 r. (Hist. Aug. Max. Balb. 1, 1) i Probusa 3 II 276 r. (Hist. Aug. Prob. 11, 5). O błędach w tych datach zob. R. Suski, op.cit., s. 33-35. Niektórzy badacze doszukiwali się w nich nawiązań do dat posiedzeń senatu w czasach Katyliny zawartych w dziełach Cycerona i Salustiusza (A. Chastagnol, Rencontres entre l'Histoire Auguste et Cicéron (a propos d'Alex. Sev. 6, 2), MEFRA 1987, 99, s. 905-919). Nie jestem przekonany do tej hipotezy, zob. R. Suski, op.cit., s. 105-106. 
pisał o Curii Pompiliana. Być może nawiązywał do Curia Hostilia, która według tradycji została wybudowana przez Tullusa Hostilliusa ${ }^{45}$. Być może Scriptor przypisał Numie Pompiliusowi jej powstanie. W każdym razie jest to fałszywa uczoność ${ }^{46}$. Wielki problem sprawiają także nazwiska osób, które miały wygłaszać mowy podczas poszczególnych etapów ogłaszania Tacyta cesarzem. O konsulu Veliusie Cornificiusie Gordianusie nie wiadomo nic poza Historia Augusta. Znając fatalną renomę tego dzieła jest więc prawdopodobne, że nie istniał ${ }^{47}$. Nic też poza Historia Augusta nie wiadomo o prefekcie pretorianów Moesiusie Gordianususie. Stąd większość badaczy uważa, że został wymyślony przez autora naszego źródła ${ }^{48}$. To samo można powiedzieć o prefekcie miasta Aeliusie Cesettianusie. Prefekt o tym nazwisku nie figuruje na liście prefektów u Chronografa z 354 roku. Jego kognomen też jest dziwaczny. Najprawdopodobniej jest więc to postać fikcyjna ${ }^{49}$.

Po trzecie, w pozostałych elementach tej narracji nie odnajdujemy większych niespodzianek narracyjnych. Najpierw konsul Velius Cornificius Gordianus przedstawia powody, dla których senat winien cesarza wybrać. Cesarstwu groziły wojny zewnętrzne i brakowało stabilizacji ${ }^{50}$. Gdy senatorowie chcą obwołać władcą Tacyta, wówczas ten wskazuje na swój wiek jako przeszkodę. Starzec mógł nie spodobać się armii ${ }^{51}$. Także mowy Aeliusa Cezatianusa (wychwala on Tacyta jako dostojnego męża, który swoimi radami przysłużył się państwu $)^{52}$ i Maeciusa Gallicanusa (wskazuje pretorianom, że senat spełnił ich prośby i dał im takiego cesarza, o jakiego prosili) ${ }^{53}$ są dosyć stereotypowe. Jak widać, w innych elementach narracji o wstąpieniu na tron Tacyta trudno dopatrzeć się jakichś aluzji do konkretnych wydarzeń politycznych, w tym do uzurpacji Eugeniusza czy bitwy nad rzeką Frygidus. Autor Historia Augusta wymyślając mowy idzie za przykładem Tukidydesa, który zalecał nie odtwarzać co powiedziano, ale co winno się było powiedzieć ${ }^{54}$. Narracja dotycząca

\footnotetext{
${ }^{45}$ Varro, LL. V 155.

${ }^{46}$ F. Paschoud (ed.), Histoire Auguste, t. 5, 1: Vies d'Aurélien, Tacite, Paris 1996, s. 194.

${ }^{47}$ T. D. Barnes, Some Persons in the Historia Augusta, "Phoenix” 1972, 26, s. 159.

${ }^{48}$ Zob. R. Syme, Emperors..., s. 75; E. Birley, Some Names in the Historia Augusta, „Bonner Historia Augusta Colloquium" 1979/1981, Bonn 1983, s. 83.

49 Zob. PLRE, T. 1, Aelius Cesettianus, s. 199; T. D. Barnes, Some Persons..., s. 154; A. Chastagnol, Histoire Auguste. Les empereurs romains des Ileme et IIIeme siecles, Paris 1994, s. 1044. Tym bardziej, że w 275 r. prefektem miasta był Postumius Suagrius (patrz: F. Paschoud (ed.), Histoire Auguste, t. 5, 1..., s. 273).

${ }^{50}$ Hist. Aug. Tac. 3, 2-7.

${ }^{51}$ Hist. Aug. Tac. 4, 5.

${ }^{52}$ Hist. Aug. Tac. 7, 2-4.

${ }^{53}$ Hist. Aug. Tac. 8, 3-5.

${ }^{54}$ Thuc. I 22, 1.
} 
wstąpienia na tron Tacyta w Historia Augusta nie jest też samoistną całością. Scriptor albo wprost odwoływał się do wiadomości przytaczanych w żywocie Aureliana ${ }^{55}$, albo nawiązywał do faktów zawartych w tej biografii (czyni aluzje do rebelii Zenobii) ${ }^{56}$. Tymczasem badacze szukając aluzji w Historia Augusta najczęściej zapominają o kontekście, w jakim znajduje się wspominany interesujący ich passus ${ }^{57}$.

Po czwarte, o ile Hartke i Honoré mieli rację, że Aurelian umarł bezpotomnie (a przynajmniej nie ma najmniejszej przesłanki, która kazałaby sądzić inaczej), to według Scriptora dochował się on córki. W biografii Aureliana pisał o podarunkach, jakie cesarz dawał podczas sigillariów swojej żonie i córce. Podczas sprawowania władzy nie był on bardziej szczodry, niż gdy był osobą prywatną ${ }^{58}$. Czytelnik dowiedział się także, że owa córka była jedynym dzieckiem imperatora, a jej potomkowie żyli do czasów wymyślonego powstania Historia Augusta w Rzymie (czyli panowania Dioklecjana i Konstantyna Wielkiego ${ }^{59}$. Synem córki Aureliana miał być senator Aurelianus, prokonsul Cylicji, który miał żyć na Sycylii i był człowiekiem wszelkich dobrych przymiotów (Scriptor sugeruje, że był osobą żyjąca, gdy pisał $)^{60}$. Ów senator Aurelianus nie jest znany poza Historia

${ }^{55}$ Hist. Aug. Aurel. 2, 4; 2, 5.

${ }^{56}$ Hist. Aug. Tac. 3, 5.

${ }^{57}$ Mimo swojej niesławy autor Historia Augusta nie jest bezwolnym pisarzem. Warsztat Scriptora dobrze pokazuje jego narracja dotycząca 238 r., dla której zachowało się główne jego źródło czyli Herodian. Scriptor streszcza swoje główne źródło, ale jest wobec niego krytyczny. Kiedy nie zgadza się z jego przekazem, to polemizuje z nim. W narrację Herodiana wplata informacje pochodzące z innego źródła, które identyfikuje się z Dexipposem. Aby uwiarygodnić swój przekaz, wymyśla dokumenty, które są zgodne z jego narracją (zob. R. Suski, op.cit., s. 28-33). Co więcej, liczne zmyślenia zawarte w Historia Augusta pokazuja że jej autor musiał bardziej niż inni antyczni historycy dbać o spójność swojego dzieła. Nie będąc ograniczony przez fakty historyczne, musiał bardziej uważać niż inni autorzy na niezgodności pomiędzy poszczególnymi żywotami. Wplatał często fikcję w swój przekaz (przy czym szczególnie dotyczyło to losów przyszłych władców przed wstąpieniem na tron oraz cech ich charakteru, a także biografii uzurpatorów, we wszystkich tych przypadkach po prostu brakowało mu realnej wiedzy), ale trudno mu zarzucić brak panowania nad przytaczanym materiałem. Autor Historia Augusta w tym względzie przypomina Kadłubka, który też tworzył nową wzbogaconą wersję bajecznych dziejów Polski. Kadłubek także fantazjował, ale trudno mu odmówić w tym zamysłu i spójności.

${ }^{58}$ Hist. Aug. Aurel. 50, 2, „uxori et filiae annuum sigillaricium quasi privatus instituit”. O Sewerynie żonie Tacyta zob. R. Suski, Interregnum i Seweryna. Czy kobieta była cesarzem?, „Antiquitas" 2007, 29, s. 645-664.

${ }^{59}$ Hist. Aug. Aurel. 42, 1, „Aurelianus filiam solam reliquit, cuius posteri etiam nunc Romae sunt".

${ }^{60}$ Hist. Aug. Aurel. 42, 2, „Aurelianus namque pro consule Ciliciae, senator optimus sui vere iuris vitaeque venerabilis, qui nunc in Sicilia vitam agit, eius est nepos". 
Augusta i najprawdopodobniej jest postacią wymyśloną przez jej autora ${ }^{61}$. Ponadto według Scriptora także prefekt miasta z czasów Dioklecjana C. Iunius Tiberianus miał być spokrewniony z cesarzem - wywodził swoje pochodzenie $\mathrm{z}$ jego $\mathrm{krwi}^{62}$. O ile prefekt jest osobą prawdziwą ${ }^{63}$, to jego rozmowa z autorem Historia Augusta jest oczywiście kompletną fantazją ${ }^{64}$ i jest mało prawdopodobne, aby zgłaszał on pretensje do pochodzenia od Aureliana $^{65}$. To jest jednak nieistotne. Czytelnik Historia Augusta mógł odnieść wrażenie, że ród cesarza nie wymarł i zapewne należał do elity senatorskiej Najwidoczniej jacyś senatorowie w czasach, gdy powstała Historia Augusta, doszukiwali się w Aurelianie swojego antenata ${ }^{66}$.

${ }^{61}$ F. Paschoud (ed.), Histoire Auguste, t. 5, 1, s. 196-197.

${ }^{62}$ Hist. Aug. Aurel. 1, 3, „,cumque ad Templum Solis venissemus ab Aureliano principe consecratum, quod ipse non nihilum ex eius origine sanguinem duceret, quaesivit a me quis vitam eius in litteras rettulisset".

${ }^{63}$ C. Iunius Tiberianus w fasti pojawia się jako konsul zwyczajny w 281 r. (razem z Probusem) oraz 291 r. (z Cassiusem Dio, który był wnukiem lub prawnukiem historyka Kasjusza Diona). Był on też dwukrotnie prefektem miasta: w 291 r., a następnie w latach 303-304. W III w. piastowanie konsulatu zwyczajnego dwukrotnie w ciągu 10 lat było bardzo niezwykłe. Gdy senatorowie doznali zaszczytu dwukrotnego sprawowania funkcji konsula zwyczajnego w tym czasie, to pomiędzy konsulatami mijało ponad 20 lat (C. Octavius Suetrius Sabinus konsul zwyczajny w latach 214 i 240, oraz L. Valerius Maximus konsul zwyczajny w latach 233 i 256). Stąd zaproponowano, że w rzeczywistości mamy do czynienia z dwoma Iuniusa Tiberianusami - ojcem i synem. Pierwszy z nich byłby dwukrotnie konsulem - po raz pierwszy jako konsul dodatkowy, a następnie w $291 \mathrm{r}$. Był on też prefektem miasta w 291 r. Jego syn i imiennik byłby konsulem w 281 r., oraz prefektem miasta w latach 303-304 (A. Chastagnol, Les fastes de la préfecture de Rome au Bas-Empire, Paris 1962, s. 17-20; M. Christol, Essai sur l'évolution des carriěres sénatoriales dans la seconde moitié du IIIe siěcle ap. J.C., Paris 1986, s. 204-206). Ta hipoteza została dosyć powszechnie przyjęta, choć opiera się jedynie na założeniu, że dostęp do prestiżowych funkcji był tak skonwencjonalizowany, że nie istniały odstępstwa od ogólnych reguł.

${ }^{64} \mathrm{O}$ tym passusie zob. D. den Hengst, The Prefaces in the Historia Augusta, Amsterdam 1981, s. 94-102.

${ }^{65}$ Można oszacować, kiedy on się urodził. C. Iunius Tiberianus był trybunem wojskowym legionu X Geminae Decianae w 249 r. (CIL III 4558 z Vindobony). Urodził się więc ok. 229 r., gdy Aurelian miał ok. 15 lat. Patrz: D. den Hengst, op.cit., s. 101-102.

${ }^{66}$ Niedawno sugerowano, że biografia Aureliana może być ukrytym panegirykiem ku czci konsula z 400 r. Aureliana (B. Pottier, L'Histoire Auguste, le consul Aurelianus et la réception de la Notitia Dignitatum en Occident, "Antiquité Tardive” 2006, 14, s. 225-234). Ten sam badacz upatruje w żywocie Maksymina Traka paszkwilu na wroga tego Aureliana Stylichona. Zob. B. Pottier, Un pamphlet contre Stilichon dans l'Histoire Auguste: la vie de Maximin le Thrace, MÉFRA 2005, 117, s. 223-267. Stanowczo nie doszukiwałbym się jednak w passusach dotyczących potomków Aureliana nawiązań do tego polityka. Nie tylko dlatego, że konsul z 400 r. związany był ze wschodem, a nie z Italią. Szukanie aluzji do postaci historycznych w dziele, w którym ukryto czas jego powstania, jest wielce ryzykowne. Dlatego nie szukam w żadnym ze znanych Aurelianusów z IV-V wieku domniemanych potomków Aureliana. Wśród polityków o tym nazwisku w IV-V wieku można by wymienić: Aurelianusa, prefekta Annony w 367 r. (C. Th. XIII 6, 5), Aurelianusa prokonsula Azji 
Co ciekawe, to nie jest jedyny przypadek, w którym sugeruje się istnienie potomków cesarzy panujących w drugiej połowie III wieku w Historia Augusta (Klaudiusza II, Aureliana, Tacyta i Probusa). Jej autor twierdzi, że Konstancjusz Chlorus i Konstantyn Wielki pochodzili z rodu Klaudiusza $\mathrm{II}^{67}$. W tym wypadku mamy do czynienia z nawiązaniem do propagandy Konstantyna Wielkiego, która upatrywała w Klaudiuszu II dziadka cesarza $^{68}$. Oczywiście była to czysta fantazja, która motywowana była sytuacją polityczną po zamordowaniu Maksymiana Herkulijskiego ${ }^{69}$. Propaganda tego władcy (i Juliana) wpłynęła na przekaz kilku antycznych historyków. Według autora Excerpta Valesiana Konstantyn Wielki był wnukiem brata Klaudiusza $\mathrm{II}^{70}$, a Eutropius czynił go synem córki tego władcy ${ }^{71}$. A ponieważ Eutropius i Historia Augusta korzystali z Kaisergeschichte (jeżeli rzeczywiście powstała), to być może stamtąd Scriptor zaczerpnął informację o związkach Klaudiusza II i Konstantyna Wielkiego.

w 395 roku (C. Th. XVI 5, 28), Aurelianusa adresata listu Symmachusa (Sym. Ep. IX 26), Aurelianusa praefectusa praetorium (Galii? Iryllicum?) w 473 r. czy Aurelianusa znanego z inskrypcji w Kolosseum (CIL VI 32116).

${ }^{67} \mathrm{~W}$ biografii Klaudiusza II Scriptor wspomina o rodzeństwie cesarza (w większości wymyślonym), w tym braciach Crispusie i Quintillusem (jedyna postać autentyczna w tym zestawieniu). Według Scriptora Crispus był ojcem Claudii, żony senatora Eutropiusa. Konstancjusz Chlorus był dzieckiem tej pary (Hist. Aug. Claud. 13, 1-2). W żywocie Aureliana mowa jest o zwróceniu się cesarza do druidek. Pytał się on kapłanek, czy jego potomkowie zostaną cesarzami. Druidki miały odpowiedzieć, że żadne imię nie będzie tak słynne, jak Claudiusa II. Autor Historia Augusta dodaje, że Konstancjusz Chlorus wywodził się z rodu Klaudiusza II (Hist. Aug. Aurel. 44, 3-4). W tym passusie wspominane są druidki, które nie są poświadczone poza tym źródłem. Najprawdopodobniej zostały one wymyślone przez Scriptora. To kolejny przykład fałszywej uczoności autora Historia Augusta. Zob. R. Wiśniewski, Si fama non fallit fidem, les druides dans la littérature latine de l'Antiquité tardive, „Antiquité Tardive” 2009, 17, s. 307-315.

${ }^{68}$ Pan. Lat. VII 21, 2.

${ }^{69}$ W 310 r. poniósł śmierć Maksymian Herkulijski. Nie jest jasne, czy powieszono go, czy do tego go zmuszono. W każdym razie stało się to z rozkazu jego zięcia Konstantyna Wielkiego. To w jakimś stopniu zakwestionowało legitymizację władzy Konstantyna Wielkiego. We wygłoszonym w 310 r. panegiryku opisano nie tylko pochodzenie Konstantyna od Klaudiusza II, ale też jego spotkanie Apollona, który zapowiedział mu 30 lat rządów. Zob. R. Syme, The Ancestry of Constantine, „Bonner Historia Augusta Colloquium” 1971, Bonn 1974, s. 237-253; T. D. Barnes, Constantine and Eusebius, London 1981, s. 35-37; T. Kotula, Cesarz Klaudiusz II i Bellum Gothicum lat 269-270, Wrocław 1994, s. 9-11. Niektórzy badacze dopuszczają możliwość, że Konstantyn Wielki mógł być potomkiem Klaudiusza II (Ch. M. Odahl, Constantine and the Christian Empire, London-New York 2010, s. 318). To czysty absurd. Część źródeł nie wie nic o relacjach Konstantyna Wielkiego z Klaudiuszem II. Ci, którzy przytaczali ten fakt, nie byli zgodni, jak obaj władcy byli ze sobą spokrewnieni.

${ }^{70}$ Anon. Val. 1, 2.

${ }^{71}$ Eutrop. Brev. IX 22, 1. 
O ile o domniemanych potomkach Klaudiusza II wspominało kilka źródeł, to w przypadku kolejnych imperatorów wymienia ich tylko $\mathrm{Hi}$ storia Augusta. Jak czytelnik pamięta, w mowie Maeciusa Faltoniusa Nicomachusa wzmiankowani są synowie Tacyta. Scriptor powrócił do tematu jego potomków, opisując uderzenie pioruna w marmurowe pomniki Tacyta i Florianusa w Interamnie. Haruspikowie po tym wydarzeniu mieli przepowiedzieć nastanie cesarza, który będzie pochodził z rodziny tych władców. Jego rządy miały nastąpić tysiąc lat po tym wypadku. Ów imperator miał podporządkować Rzymowi Partów, Persów, Franków, Alamanów, Sarmatów, Cejlon, Irlandię. Miał on dożyć 120 lat i umrzeć bez spadkobiercy ${ }^{72}$. Być może passusy należy rozumieć jako aluzję do jakiegoś bliżej nieznanego dla nas rodu senatorskiego, który zaliczał do swoich antenatów tego imperatora ${ }^{73}$. Także następca Tacyta Probus miał według Historia Augusta pozostawić po sobie potomków. Mieli oni uciec z Rzymu w okolice Werony, w pobliże jezior Benakus i Larius. Ponadto Scriptor wspomina o uderzeniu piorunu w posąg Probusa, który znajdował się w okolicach Werony ${ }^{74}$. Także to wydarzenie zostało zinterpretowane przez haruspików jako zapowiedź sławy i objęcia wysokich urzędów przez potomków Probusa ${ }^{75}$. Co prawda nic nie wiemy o rzeczywistych potomkach tego władcy, ale za to być może potrafimy wskazać, do jakiego rodu może

${ }^{72}$ Hist. Aug. Tac. 15, 1-5. Passus ten jest bardzo ciekawy. Po pierwsze, widzimy w nim zapowiedź przywrócenia republiki przez władcę z rodu Tacyta. Po drugie, wyśmiewa się w nim przepowiednie haruspików, twierdząc, że bezpiecznie jest mówić o dalekiej przyszłości, której ziszczenia nie dożyje nikt, kto by ją pamiętał. Jak na gorliwego czciciela dawnych bogów jest to dziwna konstatacja. Po trzecie, uderzenie piorunu, które zawsze było znakiem złowrogim, jest zapowiedzią pozytywnej przyszłości. Jak na poganina, to również jest bardzo dziwna reinterpretacja znaczenia zjawiska atmosferycznego (zob. P. Janiszewski, Żywioły w stużbie propagandy, czyli po czyjej stronie stoi bóg. Studium klęsk i rzadkich fenomenów przyrodniczych u historyków kościoła IV i V wieku, [w:] Chrześcijaństwo u schyłku starożytności. Studia źródłoznawcze, t. 3, red. T. Derda, E. Wipszycka, Kraków 2000, s. 74). Po czwarte, okres tysiąca lat, po którym nastąpi przełom, zbyt mocno kojarzy się z chrześcijańskim millenaryzmem. O tym passusie zob. J. Schwartz, Du millénarisme dans l'«Histoire Auguste», „Bonner Historia Augusta Colloquium” 1971, Bonn 1974, s. 157-163; F. Paschoud (ed.), Histoire Auguste, t. 5, 1, s. 305-309. Dla nas jest istotne, że tekst wyraźnie sugeruje, że istnieją w czasach jego powstania (fikcyjni) potomkowie Tacyta.

${ }^{73}$ Cognomen Tacitus nie jest poświadczony dla IV-V wieku. Przyszły cesarz z rodu Tacyta i Floriana mógł być według Scriptora potomkiem cesarzy w linii żeńskiej, więc jego nomen i cognomen nie musi przypominać nazwisk obu władców. Zob. P. Janiszewski, op.cit., s. 75 .

${ }^{74}$ Także w tym wypadku uderzenie piorunu zostało przedstawione jako pozytywny znak. Nie tylko pod tym względem ten passus jest bardzo podobny do tego z biografii Tacyta. W obu jest on powodem do zasięgnięcia opinii haruspików. Zob. P. Janiszewski, op.cit., s. 77.

${ }^{75}$ Hist. Aug. Prob. 24, 1-3. 
to być aluzja. Otóż według Scriptora Probus był krewnym Klaudiusza II, a jego siostra nosiła imię Claudia ${ }^{76}$. Wspomniani przez Historia Augusta potomkowie Probusa mogą być nawiązaniem do Claudiusa Petroniusa Probusa, w którego imieniu mamy zarówno kognomen Probus, jak i Claudius ${ }^{77}$.

W tym miejscu powstaje pytanie, czy przypisanie Aurelianowi, Tacytowi i Probusowi posiadania potomków, którzy zasiadali w senacie, jest wymysłem autora Historia Augusta, czy też jest ukłonem w stronę rzymskich rodów senatorskich doszukujących się w cesarzach swoich antenatów. Za tą drugą hipotezą może przemawiać fakt postrzegania Petroniusa Maximusa jako potomka Magnusa Maximusa ${ }^{78}$. Byłoby to niezwykle ciekawe. Otóż jak wiadomo przyznawanie się do pokrewieństwa z rzymskim cesarzem z jednej strony było zaszczytem (i legitymizowało starania się o tron), ale drugiej z tych samych powodów często było niebezpieczne. Sprawujący władzę często likwidowali potomków dawnych cesarzy, nawet gdy ci nie zagrażali im. Członkowie rodzin władców byli zabijani nie tylko po ich obaleniu (lub ginęli z rozkazu swoich krewnych), czasami mijały lata, gdy spotykał ich smutny koniec. Często przyczyną mordu były większe prawa do tronu niż sprawujących władzę. Tak na przykład Karakalla kazał stracić syna Pertinaksa P. Helviusa Pertinaxa ${ }^{79}$, córkę Mar-

${ }^{76}$ Hist. Aug. Prob. 3, 3

${ }^{77} \mathrm{~W}$ pobliżu Werony znajdowały się posiadłości należące do rodziny Petroniusa Probusa (CIL V 3344 = ILS 1266; CIL VI = ILS 1265). Rodzina ta od dawna zasiadała $w$ senacie i osiągała najwyższe urzędy. Jego przodkami byli dziadek Petronius Annianus (cos. 314, PPO 315-317) i ojciec Petronius Probinus (cos. 341, PVR 345-456). Sam Sex. Claudius Petronius Probusa był prokonsulem Afryki w 358 r., PPO Illyrici w 364 r., PPO Galliarum w 366 r., PPO Illyricum, Italii i Afryki w latach 368-375, cos. 371, PPO Italii i Afryki w 383 r. Zmarł ok. 388 r. Był chrześcijaninem związanym z Anicjuszami (jego żoną była Anicia Faltonia Proba). Jego synami byli Anicius Probinus (Cos. 395, prokonsul Afryki 396-397), Anicius Hermogenianus Olybrius (cos. 395), Anicius Petronius Probus (cos. 406, był on gorliwym chrześcijaninem) i Anicia Proba. Prawdopodobnie potomkiem Aniciusa Hermogenianusa Olybriusa był Anicius Olymbrius (patrycjusz, cos. 464, cesarz zachodniorzymski w 472 r.). Być może passus zawarty w Historia Augusta nawiązuje do pochwał Hieronima (Hier. Ep. 130, 3) i Panegiryku Claudianusa (11-14) pod adresem synów Claudiusa Petroniusa Probusa po osiągnięciu przez nich konsulatu w 395 roku. O tym passusie patrz: F. Paschoud, Histoire August,. t. 5, 2 Vies de Probus, Firmus, Saturnun, Proculus et Bonose, Carus, Numérien et Carin, Paris 2001, s. 162-165. O Petroniusie Probusie patrz: A. Cameron, Polyonomy in the Late Roman Aristocracy The Case of Petronius Probus, JRS 1985, 75, s. $164-182$.

${ }^{78}$ Proc. BV I 4, 16.

${ }^{79}$ Herod. IV 6, 3; Hist. Aug. Ca. 4, 8-9; Hist. Aug. Get. 6, 7-8. Zob. D. Okoń, Severi et senatores. Polityka personalna cesarzy dynastii Sewerów wobec senatorów w świetle badań prozopograficznych (193-235 r. n.e.), Szczecin 2009, s. 123-124. 
ka Aureliusza Annię Cornificię Faustinę $e^{80}$, wnuka Marka Aureliusza Claudiusa Pompeianusa ${ }^{81}$. Licynius kazał zamordować syna dawnego cesarza Severusa Severianusa, syna swojego przyjaciela i poprzednika Galeriusza Candidianusa, syna Maksymina Dai, stracono też żonę Dioklecjana Priscę $\mathrm{i}$ ich córkę oraz wdowę po Galeriuszu Valerię ${ }^{82}$. W czasach panowania synów Konstantyna Wielkiego nie tylko nie żył już żaden potomek tetrarchów, który nie wywodził się z rodu Konstancjusza Chlorusa, ale podczas czystki po śmierci Konstantyna Wielkiego wymordowano jego braci, większość bratanków i część dalszych powinowatych ${ }^{83}$. Wyjątkiem był jedynie los potomków córki Marka Aureliusza Anni Aurelii Galerii Faustiny, którzy znani są jeszcze w IV w. ${ }^{84} \mathrm{O}$ ile bycie męskim potomkiem władcy było niebezpieczne, to większe szanse przeżycia miały córki/żony byłego cesarza. Przez małżeństwo z córką byłego władcy można było legitymizować swoje rządy. To dlatego Gracjan ożenił się z Constantią córką Konstancjusza II ${ }^{85}$, Walentynian I z Justyną wdową po Magnencjuszu ${ }^{86}$, a Teodozjusz I z Gallą córką Walentyniana I ${ }^{87}$. W czasach panowania rodu Walentyniana I i dynastii teodozjańskiej starano się nie wydawać za mąż córek cesarzy, tak aby nie tworzyć konkurencji wobec władcom ${ }^{88}$. Dopiero w późnym cesarstwie rzymskim potomkowie dawnych władców mogli

${ }^{80}$ Cas. Dio LXXVIII 16, 6.

${ }^{81}$ Herod. IV 6, 3; Hist. Aug. Ca. 3, 8. Zob. D. Okoń, op.cit., s. 123-124.

${ }^{82}$ Lact. Mort. Pers. 50-51.

${ }^{83}$ Zob. S. Tougher, Imperial Blood: Family Relationships in the Dynasty of Constantine the Great [w:] M. Harlow, L. Larsson Loven (ed.) Families in the Roman and Late Antique World, London-New York 2012, s. 181-198.

${ }^{84}$ Annia Aurelia Galeria Faustina została żoną Cn. Claudiusa Severusa i matką Ti. Claudiusa Severusa Proculusa (cos. 200). Ten ożenił się z swoją kuzynką Annią Faustiną (wnuczka siostry Marka Aureliusza) i doczekał się z nią córki Anni Faustiny, która na krótko została augustą jako trzecia żona Heliogabala. Pierwszemu swojemu mężowi Pomponiusowi Bassusowi urodziła dwoje dzieci: Pomponię Ummidię i Pomponiusa Bassusa. Pomponia Ummidia została żoną Flaviusa Antiochanusa (cos. 270). Pomponius Bassus był jednym z najznaczniejszych senatorów swoich czasów. Nie tylko był on dwukrotnie konsulem (cos. 259, 271), ale w Epitome de Caesaribus nazywa się go princepsem senatu za panowania Klaudiusza II (Epit. 34, 3). Jego córką była Pomponia Bassa, którą wydano za Luciusa Septimiusa Severusa. Dzieckiem tej pary był Septimius Bassus (PVR 317-319).

${ }^{85}$ Amm. Marc. XXIX 6, 7.

${ }^{86}$ Soc. Hist. Eccl. IV 31.

${ }^{87}$ Soc. Hist. Eccl. IV 31.

${ }^{88}$ Nie ożeniono Justy i Graty, córek Walentyniana I (Soc. Schol. Hist. Eccl. IV 31). Dziewictwo ślubowała Pulcheria córka Arkadiusza (Soz. Hist. Eccl. IX 1), a w ślad za nią poszły jej siostry Arcadia i Marina (Soz. Hist. Eccl. IX 3). Wreszcie Justa Grata Honoria pozostając panną miała romans, zaszła w ciążę z Eugeniuszem (Joh. Ant. fr. 199, 2). W tym czasie była już najprawdopodobniej kobietą po trzydziestce (choć zaznaczmy, że interpretacja źródeł o jej romansie jest dyskusyjna i jego datacja niepewna), co jednoznacznie świadczy o tym, że nie chciano jej wydać za mąż. 
czuć się bezpieczniej. Tak Procopius Patricius (od 422 r.) i comes rei militaris w latach 422-424 miał być potomkiem Procopiusa uzurpatora z czasów Walensa ${ }^{89}$. Synem tego patrycjusza był Antemiusz, który ożenił się z córką Marcjana Marcią Euphemią ${ }^{90}$. Następcą Marcjana został jednak Leon I, który pozbył się Antemiusza, czyniąc go cesarzem Cesarstwa Zachodniorzymskiego. Także synowie Antemiusza Marcian, Procopius Anthemius i Romulus nie zostali zlikwidowani przez cesarzy wschodniorzymskich. Nawet gdy Marcjan podniósł bunt przeciw Zenonowi, to jedynie został zesłany do Tarsu, gdzie otrzymał święcenia kapłańskie ${ }^{91}$. Co prawda siostrzeńcy Anastazjusza I Hypatius i Pompeius zostali straceni za panowania Justyniana Wielkiego, ale stało się to po obwołaniu ich władcami podczas buntu Nika ${ }^{92}$. Wcześniej pełnili najwyższe godności za panowania Justyna I i Justyniana i cieszyli się ich zaufaniem ${ }^{93}$. Posiadane majątki zostały skonfiskowane po ich śmierci, ale następnie zwrócone dzieciom ${ }^{94}$. Tak więc dopiero $\mathrm{w}$ bardzo późnym antyku posiadanie lub fałszywe przypisywanie sobie cesarskich korzeni było relatywnie bezpieczne i mogło przydać splendoru bez niebezpieczeństwa stracenia z rozkazu imperatora. Nie pozwala to nam bliżej datować Historia Augusta, ale świadczy o tym, że powstała pewnie dosyć późno ${ }^{95}$.

Jeśli wspominanie potomków Aureliana jest ukłonem w stronę nieznanego nam rodu senatorskiego, zmienia to sens mowy Maeciusa Falconiusa Nichomachusa. Czytelnik Historia Augusta, pamiętając o pozostawieniu przez Aureliana potomków, którzy żyli w chwili jego śmierci (córka i wnuk późniejszy senator Aurelianus), mógł zastanawiać się, dlaczego nie byli brani pod uwagę jako jego następcy. Przy tym stwierdzenie, że

\footnotetext{
AM. 5957.

${ }^{91}$ Evag. Hist. Eccl. III 26.

${ }^{92}$ Evag. Hist. Eccl. IV 13; Proc. BP I 24, 19-31, 42-56; Jord. Rom. 364; Zach. Hist. Eccl. IX 14; Zon. XIV 6, 23-29.

${ }^{93}$ Hypatius był konsulem w roku 500. W 503 r. został Magistrem militum praesentalis i dowodził podczas wojną z Persją. W 513 r. został Magistrem militum per Thracias. W latach 516-518 sprawował dowództwo na wschodzie jako Magister militum per Orientem. Ponownie piastował ten urząd w latach 520-525 i 527-529. Był on Patrycjuszem co najmniej od 525 r. Jego brat Pompeius był konsulem w 501 r. Otrzymał też tytuł Patrycjusza, choć nie jest oczywiste kiedy.

${ }^{94}$ Proc. BP I 24, 57-58; V. Dan. Scet. 9.

${ }^{95}$ Nie jest to jedyna przesłanka, która sugeruje, że to dzieło powstało później niż sądzi większość współczesnych nam badaczy. Jak wiadomo, jego autor był przywiązany do tradycji pogańskiej, podczas gdy często postrzegał świat przez pryzmat chrześcijańskich wyobrażeń, oraz jego wiedza o podstawowych rytach pogańskich była więcej niż skromna. Zob. R. Suski, Jowisz..., s. 349-358.
}

${ }^{89}$ Sid. Ap. Carm. 68-69.

${ }^{90}$ Sid. Ap. Carm. II 194-197, 481-482; Jord. Rom. 336; Evag. Hist. Eccl. II 16, Theoph. 
ów senator nie istniał, nie jest wystarczające, gdy dla czytelnika Historia Augusta był on postacią historyczną. Tymczasem mowa Maeciusa Falconiusa Nichomachusa może wytłumaczyć sytuację. Gdyby przyszły senator Aurelianus żył i był namiestnikiem Cylicji za panowania Dioklecjana lub Konstancjusza Chlorusa, to powinien się urodzić nie wcześniej niż w 260 r. ${ }^{96} \mathrm{i}$ w chwili śmierci Aureliana byłby jeszcze dzieckiem lub nastolatkiem. A przecież w mowie Maeciusa Faltoniusa Nichomachusa zwraca się uwagę, że młodzi cesarze wyrastają na złych imperatorów nie tylko ze względu na swój charakter, ale z powodu objęcia władzy w zbyt młodym wieku. To zdyskwalifikowało prawa (nieistniejącego $\mathrm{w}$ rzeczywistości) wnuka Aureliana do tronu.

W tej perspektywie dziwna mowa Maeciusa Faltoniusa Nichomachusa staje się zrozumiała. Jej celem nie było nawiązywanie do konfliktów polityczno-religijnych końca IV wieku, ale zapewnienie spójności narracji i fikcji stworzonej przez autora Historia Augusta. Przypadek w postaci nieistniejącego w rzeczywistości, ale wspomnianego przez Scriptora dziedzica Aureliana pozwala autorowi tego dzieła na stworzenie opowieści, w której spełniono warunki idealnego kandydata na władcę. Jest on senatorem, żołnierze usłuchali patres conscripti, a senat pominął nieprzygotowanego do rządzenia młodego spadkobiercę z urodzenia na rzecz najlepszego spośród senatorów ${ }^{97}$. Doszukiwanie się w niej aluzji do wydarzeń politycznych z czasów bitwy nad rzeką Frygidus może więc być zupełnie bezpodstawne ${ }^{98}$. Same imiona postaci wymienionych $\mathrm{w}$ tych passu-

\footnotetext{
${ }^{96}$ F. Paschoud, Histoire Auguste, t. 5, 1, s. 197.

${ }^{97} \mathrm{O}$ ile w tym tekście tropię „,historię prawdziwą", snobizm senatorskiej elity na upatrywanie swoich korzeni wśród dawnych cesarzy, to w opowieści o wstąpieniu na tron Tacyta możemy zobaczyć też pewien schemat narracyjny. Widzimy, jakie były rzymskie wyobrażenia dotyczące kryteriów doboru najlepszego z możliwych kandydatów do bycia cesarzem. To prowadzi nas w stronę ponadczasowych wzorców narracyjnych modelujących historyczne relacje, o których pisał J. Banaszkiewicz, analizując średniowieczne źródła historiograficzne. Przy tym w przypadku Historia Augusta (podobnie jak źródeł hagiograficznym) takie spojrzenie na dawne dzieła powinno być mało kontrowersyjne. Wszyscy wiedza, że Scriptor radykalnie rozmijał się z rzeczywistością wymyślał fakty, gdy nie mógł w swoich źródłach odnaleźć potrzebnych mu opisów wydarzeń. Kreując fikcję, budował ją na podstawie powszechnych wyobrażeń i strzępów informacji, które były mu dostępne. O metodzie i polemice z tą metodologią patrz: J. Banaszkiewicz, Podanie o Piaście i Popielu. Studium porównawcze nad wczesnośredniowiecznymi tradycjami dynastycznymi, Warszawa 2010, s. 9-44.

${ }_{98}$ To nie pierwszy przypadek w Historia Augusta, w którym badacze doszukiwali się nawiązania do bitwy nad rzeką Frygidus. W opisie bitwy pomiędzy siłami wiernymi Maksyminowi Trakowi a zrewoltowanymi zwolennikami Gordiana I i Gordiana II Historia Augusta wspominana jest burza, która przeszkodziła buntownikom i przyczyniła się do ich klęski (Hist. Aug. Gord. 16, 2). Przypomina to opis zwycięstwa wojsk Teodozjusza I nad Eugeniuszem, kiedy silny wiatr wymodlony przez Teodozjusza I miał odwrócić los
} 
sach mają na celu jedynie uwiarygodnienie fikcji. Dotyczy to nie tylko Maeciusa Faltoniusa Nichomachusa, ale także innych wspomnianych w tym passusie osób: Meliusa Cornifitiusa Gordianusa, Aeliusa Cesettianusa i Moesiusa Gordianusa. Skoro nie ma klucza interpretacyjnego, który pozwoliłby zrozumieć, dlaczego nadano im imiona, to imię mówcy w senacie (Maeciusa Faltoniusa Nichomachusa) może być równie przypadkowe, bez znaczenia, a jego rola trywialna. W badaniach nad Historia Augusta bardzo często historycy doszukują się aluzji do wydarzeń politycznych z czasów, kiedy w rzeczywistości dzieło to powstało (przy czym jak wiadomo datowano na ich podstawie czas jej napisania). Wszystkie owe aluzje musiały być dosyć mocno zawoalowane (a to w ramach mistyfikacji urządzonej przez Scriptora), a przez to dostrzegano je na podstawie bardzo słabych poszlakach. Często zapomina się, że ten sam passus miałby zupełnie inny wydźwięk w zależności od czasu, kiedy dzieło powstało ${ }^{99}$.

bitwy (Ruf. Hist. Eccl. II 33; Soc. Hist. Eccl. V 25; Soz. Hist. Eccl. VII 24). Tak więc doszukano się w passusie pochodzącym z Historia Augusta aluzji do chrześcijańskiego opisu bitwy nad Frygidus (P. Janiszewski, op.cit., s. 82-83). Jest to jednak kompletne nieporozumienie. O silnej nawałnicy, która doprowadziła do klęski sił Gordiana I i Gordiana II, wspominał także Zosimos (Zos. Hist. I 16, 1. Patrz: F. Paschoud, Zosime: Histoire Nouvelle, t. 1, Paris 1971, s. 141-142). W tym passusie Zosimos korzystał najprawdopodobniej z dzieła Dexipposa (F. Paschoud, Zosime..., s. 142), który był też podstawowym źródłem dla autora $\mathrm{Hi}$ storia Augusta dla tych czasów (A. Chastagnol, Histoire Auguste..., s. LXIV-LXVI ). Tak więc najprawdopodobniej Historia Augusta i Zosimos znaleźli informację o burzy u Dexipposa, który pisał ponad sto lat wcześniej, zanim doszło do bitwy nad rzeką Frygidus. Jeszcze słabsze są poszlaki wiążące kolejne passusy pochodzące z Historia Augusta z atmosferą lat 392-394. Wśród nich można wymienić podkreślanie negatywnych aspektów silnej pozycji eunuchów na dworze cesarskim, co miało być aluzją do pozycji Eutropiusa (Hist. Aug. Alex. Sev. 65; Hist Aug. Gord. 24), osaczenia cesarza przez frakcje na dworze, które trzymały go w ignorancji (Hist. Aug. Gord. 25, 3; Hist. Aug. Aurel. 43), niechęci do legionistów biorących udział w wojnach domowych (Hist. Aug. Prob. 23, 5) czy sympatii wobec uzurpatorów (patrz: R. Syme, Ammianus..., s. 73-74). Doszukiwanie się w tych tekstach aluzji do konkretnych wydarzeń z lat 392-394 jest mocno dyskusyjne i nie wytrzymuje krytyki. W każdym z tych przypadków może być to nawiązanie do sytuacji przed latami 90 . IV w. lub po nich.

${ }^{99}$ Wśród kilku przykładów poświadczających ową hipotezę warto wspomnieć o jednym. Według Scriptora Aleksander Sewer bardzo lubił powoływać się na zaczerpniętą od żydów lub chrześcijan tzw. złotą regułę (Hist. Aug. Alex. Sev. 51,7). Informacja jest nieznana z innych źródeł, w tym żydowskich czy chrześcijańskich. Ewidentnie jest więc ona fikcyjna, tym bardziej, że ta biografia zawiera niewiele prawdziwych informacji. Zauważmy, że złota reguła znana jest nie tylko ze świętych ksiąg żydów czy chrześcijan, ale też z pism pogańskich. A jednak Scriptor powołuje się $\mathrm{w}$ tym passusie na religie monoteistyczne. W końcu IV w. można byłoby się w tej informacji doszukać apelu o tolerancję dla pogan ze strony triumfującego chrześcijaństwa albo krytyki chrześcijan likwidujących pogańskie instytucje. W V w. mogła być świadectwem zakorzenienia autora Historia Augusta w kulturze chrześcijańskiej, która stała się głównym punktem kulturowego odniesienia. Nie ma jednoznacznych kryteriów, które pozwoliłyby wybrać, która z interpretacji tego passu- 
Ignoruje się przepadnięcie części Historia Augusta ${ }^{100}$, więc milczenie jej autora o różnych wydarzeniach nie musi być znaczące ${ }^{101}$. Analizowana w tekście mowa Maeciusa Faltoniusa Nichomachusa należy, jak powiedziano na wstępie, do jednych z najważniejszych przesłanek, na podstawie których postrzegano Historia Augusta za dzieło powstałe w latach 90. IV w. Tymczasem tekst ten można interpretować na wiele sposobów. To pokazuje słabość doszukiwania się ukrytych treści w Historia Augusta, a przez to wykorzystywania ich do jej datowania. Uważam, że należy w inny sposób podejść do datowania tego dzieła. Trzeba skupić się na analizowaniu wiedzy, jaką posiadał Scriptor. Nie można wyciągać wniosków na podstawie pojedynczych passusów, ale analizować wszystkie wzmianki zawarte w tym dziele, dotyczące danej kwestii. Należy też pamiętać, że różnice pomiędzy wydźwiękiem poszczególnych passusów mogą być

su jest najbardziej prawdopodobna, gdyż nie znamy czasu powstania dzieła. Tymczasem atmosfera religijna zawarta w tym zbiorze biografii cesarskich jest wykorzystywana do datowania go. Zob. R. Suski, Jowisz..., s. 281-285.

${ }^{100}$ W Historia Augusta brak jest biografii Filipa Araba, Decjusza, Trebonianusa Gallusa, Aemilianusa. Żywot Waleriana jest bardzo krótki, ewidentnie część jego przepadła. Dzieło zaczyna się od biografii Hadriana. Prawdopodobnie była ona poprzedzona żywotami Nerwy i Trajana, gdyż Swetoniusz skończył swoje żywoty cesarzy na Domicjanie. Zob. R. Syme, Emperors..., s. 199-203; A. R. Birley, The Lacuna in the Historia Augusta, „Bonner Historia Augusta Colloquium" 1972/1974, Bonn 1976, s. 55-62; A. Chastagnol, Histoire Auguste..., s. XLII-XLV.

${ }^{101}$ Na przykład K. P. Johne zauważył, że w Historia Augusta brak jest nawiązań do Rawenny, która od 402 r. stała się siedzibą cesarzy na rzymskich zachodzie. To według niego może świadczyć o powstaniu dzieła przed ową datą (K. P. Johne, Kaiserbiographie und Senatsaristokratie, Berlin 1976, s. 156-176). Po pierwsze jednak nie mamy całego pierwotnego tekstu Historia Augusta. Po drugie Scriptor nie musiał nawiązywać do przeniesienia się dworu cesarskiego do Rawenny, ponieważ nie znamy klucza do zawartych w jego pracy aluzji. W końcu w Historia Augusta możemy się dopatrzeć tylko jednego nawiązania do Konstantynopola i do poczucia wyższości rzymskiego senatu wobec konstantynopolitańskiego - jej autor wspomniał o doszczętnym spustoszeniu Bizancjum przez Gotów za panowania Galiena, czego efektem była kompletna depopulacja. W rezultacie w mieście miało nie być żadnej starej i znakomitej rodziny, chyba że ich przedstawiciele byli w rzymskiej armii lub odbywali podróż podczas najazdów gockich (Hist. Aug. Gal. 6, 9. Patrz: S. Ratti, Histoire Auguste, t. 4, 2, Vies des deux Valériens et des deux Galliens, Paris 2002, s. 118-119). Zauważmy, że w tym passusie nie neguje się, że w Konstantynopolu istnieją stare rody senatorskie, a jedynie wskazuje się na ich nieliczność. Passus może być nawiązaniem do senatu w Konstantynopolu, ale mógłby też być jedynie kolejną próbą ukazania upadku państwa rzymskiego za panowania Galiena i mógł pochodzić ze źródła Scriptora, czyli Dexipposa. A przecież w czasach, kiedy najprawdopodobniej działał autor Historia Augusta, Konstantynopol był siedziba cesarzy od kilku pokoleń. Przy powiększających się animozjach pomiędzy elitami w obydwu częściami imperium i poczuciu wyższości rzymskiej elity wobec wschodu jedna potencjalna aluzja do Konstantynopola i jego senatu to jest dosyć mało. Zbyt mało, aby zakładać, że Scriptor musiał koniecznie odnosić się do degradacji pozycji Rzymu. 
efektem korzystania z różnych źródeł przez Scriptora. To nie pozwala tak dokładnie datować Historia Augusta, jak chcą badacze szukający w niej aluzji do wydarzeń politycznych, ale dzięki temu można będzie uniknąć ryzykownych hipotez opartych na słabych przesłankach.

\section{BIBLIOGRAFIA:}

Baldwin B., Acclamations in the Historia Augusta, „Athenaeum” 1981, 59, s. 138-149.

Banaszkiewicz J., Podanie o Piaście i Popielu. Studium porównawcze nad wczesnośredniowiecznymi tradycjami dynastycznymi, Warszawa 2010.

Banchich Th. M., The History of Zonaras from Alexander Severus to the Death of Theodosius the Great, London-New York 2009.

M. Baranowski, Przedcesarskie gesta Probusa, czyli kariera idealnego pryncepsa w Historia Augusta, „U Schyłku Starożytności” 2014, 13, s. 85-99.

Barnes T. D., The Lost Kaisergeschichte and the Latin Historical Tradition, „Bonner Historia Augusta Colloquium" 1968/69. Bonn 1970, s. 13-43.

Barnes T. D., Some Persons in the Historia Augusta, „Phoenix” 1972, 26, s. 140-182.

Barnes T. D., Constantine and Eusebius, London 1981.

Barnes T. D., Rev. A. Lippold, Die Historia Augusta. Eine Sammlung römischer Kaiserbiographien aus der Zeit Konstantins, "Classical Review" 2000, 50, s. 306-307.

Birley A. R., The Lacuna in the Historia Augusta, "Bonner Historia Augusta Colloquium” 1972/1974, Bonn 1976, s. 55-62

Birley E., Some Names in the Historia Augusta, "Bonner Historia Augusta Colloquium” 1979/1981, Bonn 1983, s. 67-98.

Bleckmann B., Überlegungen zur Enmannschen Kaisergeschichte und zur Formung historischer Traditionen in tetrarchischer und konstantinischer Zeit, [w:] Historiae Augustae Colloquium Bonnense, Bari 1997, s. 11-37

Burgess R. W., Principes cum Tyrannis. Two Studies on the Kaisergeschichte and its Tradition, "The Classical Quarterly" 1993, 43, s. 491-500.

Burgess R. W., On the Date of the Kaisergeschichte, "Classical Philology" 1995, 90, s. 111-128.

Burgess R. W., A Common Source for Jerome, Eutropius, Festus, Ammianus, and the Epitome de Caesaribus between 358 and 378, along with Further Thoughts on the Date and Nature of the Kaisergeschichte, "Classical Philology" 2005, 100, s. 166-192.

Cameron A., Polyonomy in the Late Roman Aristocracy The Case of Petronius Probus, JRS 1985, 75 , s. $164-182$.

Cameron A., The Last Pagans of Rome, Oxford 2011.

Chastagnol A., Les fastes de la préfecture de Rome au Bas-Empire, Paris 1962.

Chastagnol A., Rencontres entre l'Histoire Auguste et Cicéron (a propos d'Alex. Sev. 6, 2), MEFRA 1987, 99, s. 905-919.

Chastagnol A., Histoire Auguste. Les empereurs romains des II e et III e siècles, Paris 1994.

Chausson F., «Severus, XVII, 5 - XIX, 4: une identification?», [w:] Historiae Augustae Colloquium Bonnense, Bari, 1997, s. 97-113.

Christol M., Essai sur lévolution des carriëres sénatoriales dans la seconde moitié du IIIe siěcle ap. J.C., Paris 1986.

Hartke W., Römische Kinderkaiser. Eine Strukturanalyse römischen Denkens und Daseins, Berlin 1951.

Hengst den D., The Prefaces in the Historia Augusta, Amsterdam 1981. 
Homo L., Les documents de l'Histoire Auguste et leur valeur historique, "Revue Historique” 1926, 151, s. 161-198, 1927, 152, s. 1-31.

Honoré T., Scriptor Historiae Augustae, JRS 1987, 77, s. 156-176

Janiszewski P., Żywioły w stużbie propagandy, czyli po czyjej stronie stoi bóg. Studium klęsk i rzadkich fenomenów przyrodniczych u historyków kościoła IV i V wieku, [w:] Chrześcijaństwo u schyłku starożytności. Studia źródłoznawcze, t. 3, red. T. Derda, E. Wipszycka, Kraków 2000, s. 11-191.

Johne K. P., Kaiserbiographie und Senatsaristokratie, Berlin 1976.

Kotula T., Cesarz Klaudiusz II i Bellum Gothicum lat 269-270, Wrocław 1994.

Lippold A., Die Historia Augusta: eine Sammlung römischer Kaiserbiographien aus der Zeit Konstantins, Stuttgart 1998.

Odahl Ch. M., Constantine and the Christian Empire, London-New York 2010.

Okoń D., Severi et senatores. Polityka personalna cesarzy dynastii Sewerów wobec senatorów w świetle badań prozopograficznych (193-235 r. n.e.), Szczecin 2009.

Paschoud F., Histoire Auguste, t. 5, 1, Vies d'Aurélien, Tacite, Paris 1996.

Paschoud F., Histoie Auguste, t. 4, 3, Vies des trente tyrans et de Claude, Paris 2011.

Paschoud F., On a recent book by Alan Cameron: The Last Pagans of Rome, "Antiquite Tardive" 2012, 20, s. 359-388.

Pottier B., Un pamphlet contre Stilichon dans l'Histoire Auguste: la vie de Maximin le Thrace, „MÉFRA" 2005, 117, s. 223-267.

Pottier B., L'Histoire Auguste, le consul Aurelianus et la réception de la Notitia Dignitatum en Occident, "Antiquité Tardive” 2006, 14, s. 225-234.

Ruciński S., Praefecti praetorio. Dowódcy gwardii pretoriańskiej od 2 roku przed Chr. do 282 roku po Chr., Bydgoszcz 2013.

Schwartz J., Du millénarisme dans l'«Histoire Auguste», „Bonner Historia Augusta Colloquium" 1971, Bonn 1974, s. 157-164.

Suski R., Interregnum i Seweryna. Czy kobieta była cesarzem?, „Antiquitas” 2007, 29, s. 645-664

Suski R., Jowisz, Jahwe, Jezus. Religie w Historia Augusta, Warszawa 2014.

Syme R., Ammianus and the Historia Augusta, Oxford 1968.

Syme R., Emperors and Biography, Oxford 1971.

Syme R., The Ancestry of Constantine, „Bonner Historia Augusta Colloquium” 1971, Bonn 1974, s. 237-253.

Tougher S., Imperial Blood: Family Relationships in the Dynasty of Constantine the Great, [w:] M. Harlow, L. Larsson Loven (ed.) Families in the Roman and Late Antique World, London-New York 2012, s. 181-198.

Wiśniewski R., Si fama non fallit fidem, les druides dans la littérature latine de l'Antiquité tardive, „Antiquité Tardive” 2009, 17, s. 307-315.

\section{ABSTRACT:}

Historia Augusta is one of the most enigmatic literary sources of Late Antiquity. Although manuscripts suggests that it was written during the reign of Diocletian or Constantine the Great most modern historians believes that it is work of one author, who probably lived many decades later than he had described. Some of contemporary researchers think that Historia Augusta was written in the last decade of the fourth century. They claim that speech delivered by Maecius Faltonius Nicomachus in the senate in the live of Tacitus is allusion to the usurpation of Eugenius. According to them this is confirmed by the fact that the previously mentioned speech is completely inappropriate to the accession of Tacitus. 
Of course author contrary to what he claims does not care about historical truth. Personally I don't belive in link between Nicomachus speech and usurpation of Eugenius. I consider it is more likely that descendants of Aurelian, Tacitus and Probus, whos we know from Historia Augusta may be reference to the roman senators in the fifth century who discerned their ancestry in the former roman emperors.

Key words: Historia Augusta, Tacitus, Aurelian, Probus, late Roman Empire, Roman Historiography

\section{NOTA O AUTORZE:}

Robert Suski - historyk starożytności, doktor habilitowany (2015 r.), absolwent Uniwersytetu Warszawskiego (magisterium 1997 r., doktorat 2005 r.), zatrudniony jako adiunkt w Zakładzie Historii Starożytnej w Instytucie Historii i Nauk Politycznych Uniwersytetu w Białymstoku. Autor monografii: Konsolidacja Cesarstwa Rzymskiego za panowania Aureliana 270-275 (Kraków 2008) i Jowisz, Jahwe, Jezus. Religie w Historia Augusta (Warszawa 2014). 